\title{
Microscope-controlled glass bead blasting: a new technique
}

This article was published in the following Dove Press journal:

Clinical, Cosmetic and Investigational Dentistry

20 January $201 \mathrm{I}$

Number of times this article has been viewed

\author{
Peter Kotschy' \\ Sascha Virnik ${ }^{2}$ \\ Doris Christ ${ }^{3}$ \\ Alexander Gagg|² \\ 'Private Practice, Vienna, Austria; \\ ${ }^{2}$ Department of Oral and Maxillofacial \\ Surgery, Central Hospital, Klagenfurt, \\ Austria; ${ }^{3}$ Klagenfurt, Austria
}

Correspodence: Sascha Virnik Department of Oral and Maxillofacial Surgery, Central Hospital/LKH Klagenfurt, St. Veiterstr. 47, A-9020 Klagenfurt, Austria Tel +43/4635382242I

Fax +43/463 5382206 I

Email andreas.virnik@lkh-klu.at
Objective: The aim of periodontal therapy is the healing of periodontal inflammation; the protection of the attachment and the alveolar bone; and the regeneration of the periodontal structures. In the therapy of periodontitis, supra- and subgingival scaling and root planing plays a main role. The procedure described combines perfect root cleaning without scaling and root planing and minimal invasive periodontal surgery without a scalpel.

Material and methods: Glass beads of $90 \mu \mathrm{m}$ were used with the kinetic preparation unit PrepStart ${ }^{\circledR}$ under a pressure of $0.5-5$ bar. This technique was practised only under visual control using the OPMI ${ }^{\circledR}$ PRO Magis microscope. Seven examinations were carried out at baseline after $3,6,12,18,24$, and 36 months.

Results: Time shows a statistically significant influence on all of the considered target variables $(P<0.0001$ for all). As the according estimate is negative, probing depth decreases over time. The major decrease seems to be during the first 6 months. Considering probing depth, plaque on the main effect root shows significant influence (again, $P<0.0001$ for all). Observations with high probing depth at the beginning were faster than those with low probing depth. The same characteristic appears by attachment level. Patients with more loss of attachment show more gain.

Conclusions: Using microscope-controlled glass bead blasting results in a perfectly clean root surface using visual control (magnification 20×). Microscope-controlled glass bead blasting is therefore a good alternative to periodontal surgery.

Keywords: periodontal therapy, microscope, periodontitis

\section{Introduction}

Using a microscope in dental therapy is not new. In combination with glass bead blasting, very good results are shown in periodontology. The advantage is that this microinvasive procedure cleans root surfaces without damaging them. Microsurgical treatment is possible without incisions or flap surgery, because it is done directly within the inflamed pocket. So the patient benefits from excellent results, and the approach is nearly painless with nearly no postoperative problems.

The treatment starts with an initial examination of the patient. ${ }^{3-5}$ After diagnosis, the general treatment options are discussed with the patient and the dental hygienist can start by cleaning the root surfaces. The dental hygienist removes biofilm and supra-and subgingival calculus with ultrasonic instruments (no scaling and root planing) and polishes all tooth surfaces. It is absolutely impossible to see all the roughness and deposits in the crevices without the microscope, not to mention to remove them. 


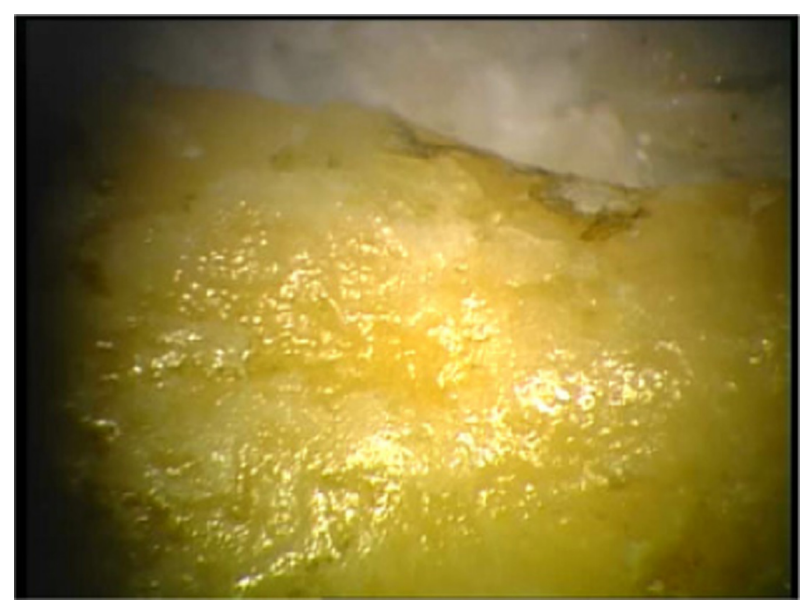

Figure I High-pressure glass bead blasting cleans root surfaces under direct undisturbed view, irrespective of the anatomy, without causing any visible damage (magnification $\times 20$ ).

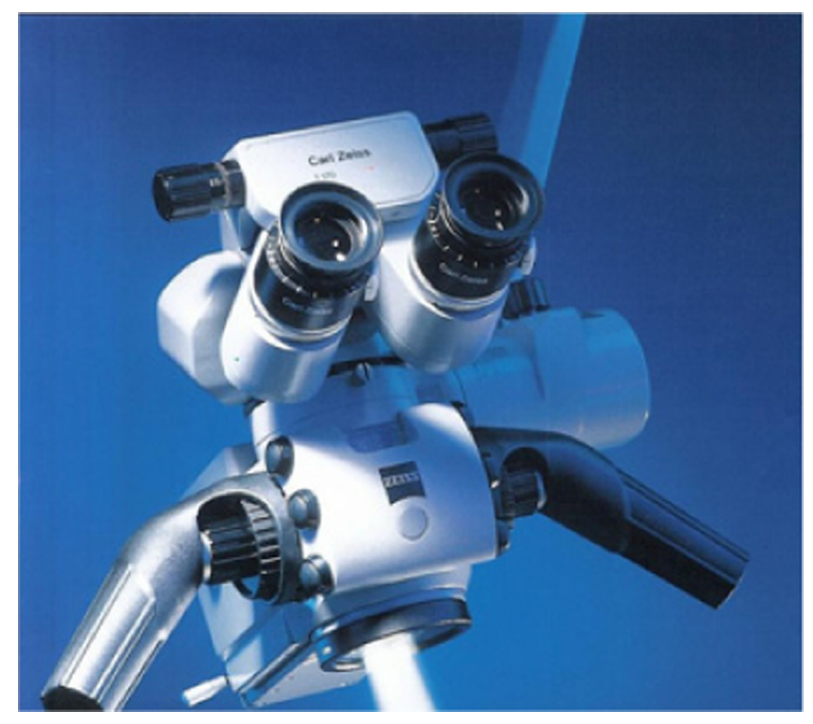

Figure 2 OPMI ${ }^{\circledast}$ PRO Magis microscope (Zeiss).

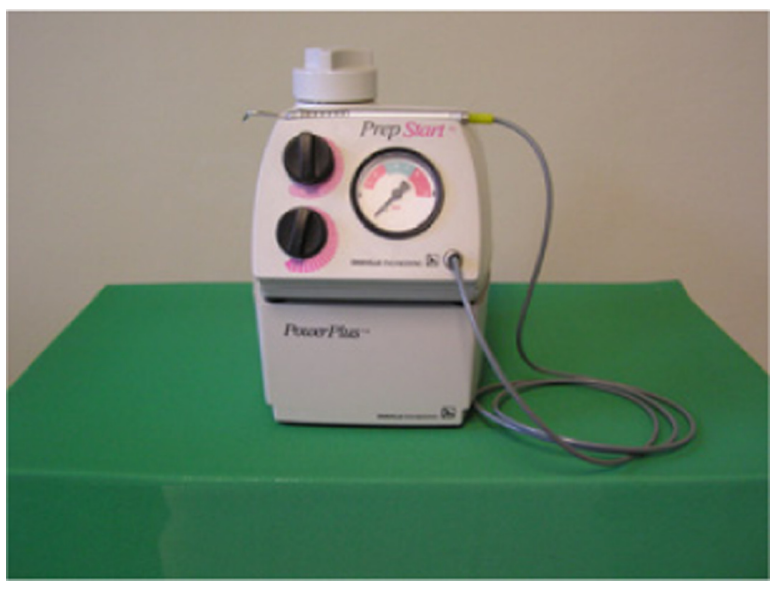

Figure 3 PrepStart ${ }^{\circledR}$ unit (Danville Engineering).
The dentist begins his or her work immediately because visual access to the pocket is needed and, after a few days, healing and shrinkage would not allow the dentist to work under visual control. A microscope is used with a magnification $\times 15-20$. The air jet opens the pocket, and the irregular root surface can be cleaned under visual control with the glass bead blasting unit. As there is always the risk of air emphysema, compression of the tissue is needed, especially around molars. If bulky deposits are visible at a microscope magnification $\times 15-20$, they can also be removed by ultrasound. Then the biofilm and all discoloration are removed and all root surfaces are cleaned with glass bead blasting without any injuries to the other structures. If needed, materials such as Emdogain ${ }^{\circledR}$ (Straumann, Basel, Switzerland) or Bio-Oss ${ }^{\circledR}$ (Geistlich, Wolhusen, Switzerland) can be used to fill infrabony pockets. ${ }^{10-19}$ As direct vision is not always possible, there are different mirrors to provide indirect vision.

All pockets are cleaned in 1-2 days to reduce the bacterial load. Glass bead blasting serves to remove all deposits, clean surfaces without visibly injuring them, debride inflamed junctional epithelium, and eliminate intrapocket bacteria. $^{20}$

The benefits compared with traditional periodontal treatment are that this procedure is minimally invasive, it allows controlled manipulation under direct vision, it involves no incisions or flaps, it is almost painless, sutures are not necessary after compression, there is no swelling or bleeding, and there are minimal aftercare measures.

The disadvantage of using this procedure is that all manipulations must be done under the microscope to ensure continual visual control.

\section{Material and methods}

The procedure began with periodontal status and was followed by a conservative and surgical pocket treatment with microscope-controlled glass bead blasting. Patients were revaluated after 3 or 6 months. If re-evaluation showed pockets deeper than $3 \mathrm{~mm}$, the procedure was repeated. The author used $90 \mu$ glass beads with the kinetic preparation unit PrepStart ${ }^{\circledR}$ (Danville Engineering, Danville, CA, USA) under a pressure of $0.5-5$ bar and practised this technique only under visual control using his preferred microscope $\mathrm{OPMI}^{\circledR}$ PRO Magis by Zeiss (Germany). ${ }^{22}$

Protecting the soft tissue from air insufflations is important. Only very sensitive patients need anesthetic for the procedure, because the structures are possibly numbed by the air jet. 


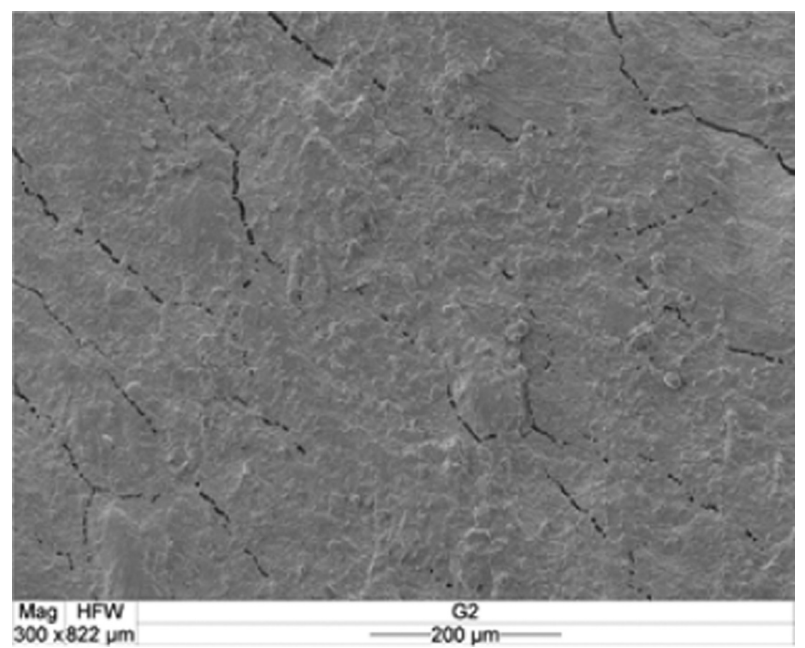

Figure 4 Half-tooth, untreated.

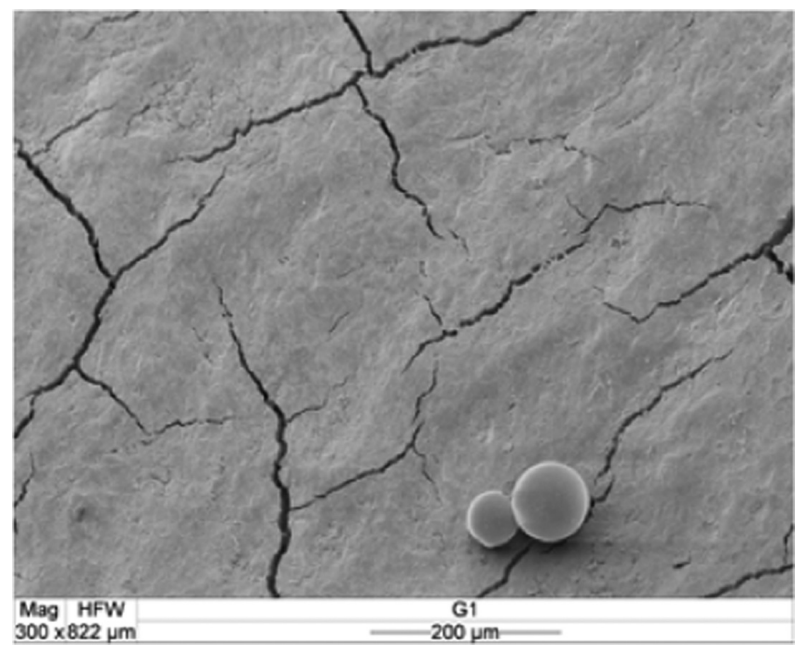

Figure 5 Same half-tooth, blasted with 5 bar for 20 seconds.

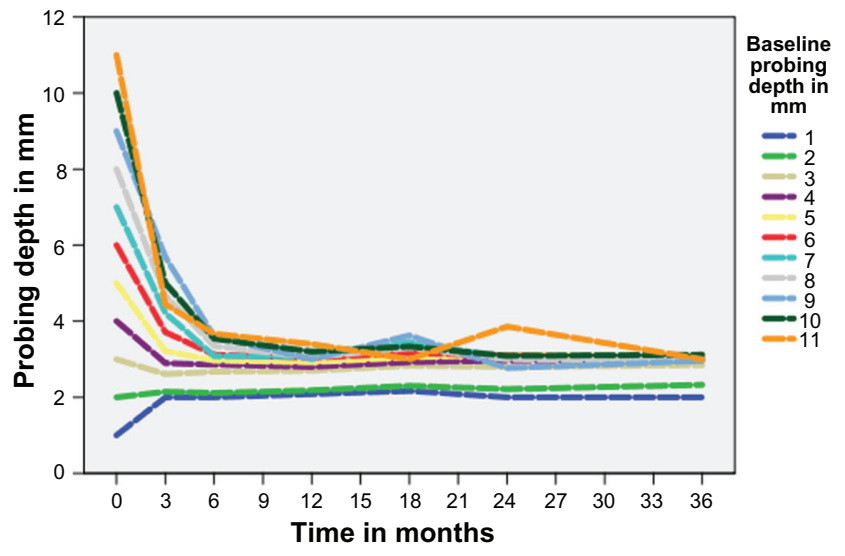

Figure 6 Observations with high probing depth at the beginning decreases very quickly, whereas observations with low probing depths at the beginning stay similar over the whole time period. After 6 months, all probing depths level off to values between 2 and 4 .

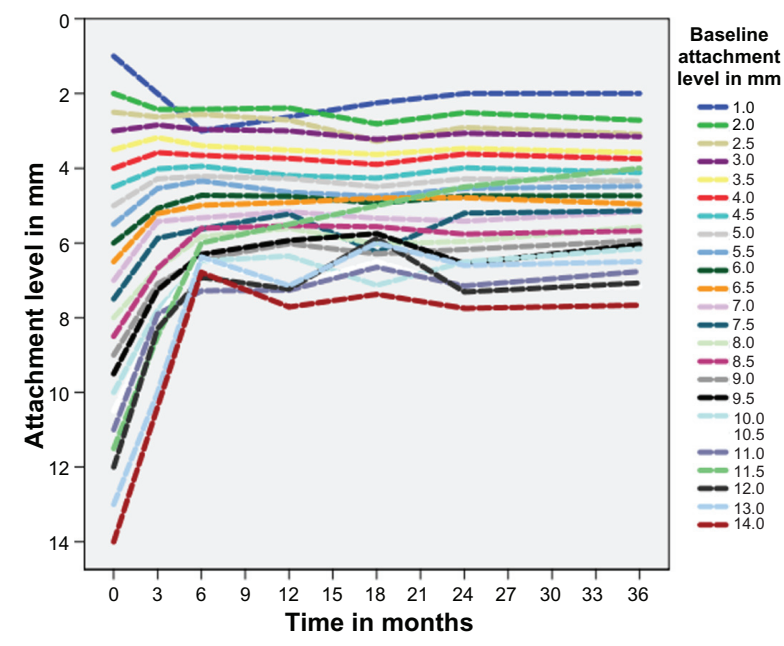

Figure 7 Related characteristics appear for attachment level. The only difference is that the variation between the different attachments levels is higer. After 6 month, all values stay between attachment levels of $2 \mathrm{~mm}$ and $8 \mathrm{~mm}$. Then, no big changes over time can be seen.

Seven examinations were carried out at baseline after 3 , $6,12,18,24$, and 36 months. Not all patients were regarded at each time point, so the sample size may have differed.

Observations with high probing depth at the beginning were faster than those with low probing depth. The same characteristics appeared by attachment level; patients with more loss of attachment showed more gain.

The ethical guidelines of the World Health Organization, the Declaration of Helsinki, and the Austrian Law of Dentists were followed.

\section{Statistical analysis}

Descriptive statistics (mean, median, standard deviation, minimum, maximum, and frequencies) for all collected variables at baseline and after 36 months are presented. The influence of the teeth roots on the target variables (probing depth, attachment level, bleeding on probing, plaque, Emdogain, Bio-Oss, periodontal tunnel flap surgery, OP, and GV over time) were determined using generalized linear mixed models with the fix factors root and time, and random factors patients and teeth nested in root, and localizations as repeated measures were calculated. Additionally, pair-wise comparisons of the different roots were performed. Plots over time were drawn. Analysis was performed using SAS 9.1 (SAS Institute Inc., Cary, NC, USA). All $P$-values $<0.00625$ were considered statistically significant. The critical boundary of 0.00625 results from the correction for multiplicity according to Bonferroni, due to the number of tests (eights tests were performed, $0.05 / 8=0.00625$ ). 
Table I Attachment level and probing depth at baseline and 36 months

\begin{tabular}{llllllll}
\hline Variable & $\mathbf{n}$ & Mean & Median & SD & Minimum & Maximum & Missing \\
\hline CPD_0 & 4406 & 3.65 & 3.00 & 1.61 & 1.00 & 11.00 & 64 \\
AL_0 & 4374 & 4.79 & 4.00 & 2.24 & 1.00 & 14.00 & 96 \\
CPD_36 & $387 I$ & 2.81 & 3.00 & 0.55 & 1.00 & 9.00 & 590 \\
AL_36 & 3839 & 4.10 & 4.00 & 1.33 & 2.00 & 631 \\
\hline
\end{tabular}

Abbreviations:

\section{Results}

Twenty-four patients participated in the study; in each patient, one to 32 teeth were treated with glass beads. Changes to the probing depth and the attachment level for all patients were with glass beads. All in all, 4470 measuring points on 500 teeth were observed. There were 290 front teeth and single-rooted premolars, and 61 double-rooted premolars and molars. Patients were observed over a time period of 36 months. There was one dropout after 12 months. Additionally, four teeth were extracted in other patients. Not all observed teeth of a patient and not all observed localizations of a tooth were measured at each time point. Further descriptive results are given in Table 1 and Table 2.

Time shows a statistically significant influence on all of the considered target variables $(P<0.0001$ for all). As the according estimate is negative, probing depth decreases over time. The major decrease seems to be during the first 6 months.

Considering probing depth, plaque on the main effect root shows significant influence (again, $P<0.0001$ for all). Those pair-wise comparisons that show significant results all have negative estimates. Therefore, single-rooted premolars and premolars have significantly lower probing depth and less plaque than molars. Additionally, double-rooted premolars have significantly lower probing depth and less plaque than molars. All other pair-wise comparisons in these variables showed no significant results.

Attachment level, bleeding on probing, OP, Emdogain, and Bio-Oss showed no significant influence $(P=0.3$

Table 2 Description of the variables at baseline and 36 months

\begin{tabular}{lllllll}
\hline Baseline & BOP & Plaque & OP & GV & EM & BIO \\
\hline 0 & 2982 & 3356 & 4347 & 4252 & 3939 & 4382 \\
I & 1424 & 1050 & 59 & 154 & 467 & 24 \\
Missing & 64 & 64 & 64 & 64 & 64 & 64 \\
\hline $\mathbf{3 6}$ months & BOP & Plaque & OP & GV & EMD & BIO \\
\hline 0 & 3832 & 3816 & $387 \mid$ & 3867 & 3794 & 387 I \\
I & 39 & 55 & 0 & 4 & 77 & 0 \\
Missing & 599 & 599 & 599 & 599 & 599 & 599 \\
\hline
\end{tabular}

Abbreviations: BIO, Bio-Oss; BOP, bleeding on probing; EMD, Emdogain; GV, ((Author to define)); OP, ((Author to define)). attachment level, $P=0.4$ bleeding on probing, $P=0.5 \mathrm{OP}$, $P=0.1$ Emdogain, $P=0.2$ Bio-Oss). Detailed results can be seen in Table 3.

\section{Discussion}

The results show an overall significant reduction of periodontal probing depth from $3.65 \mathrm{~mm}$ to $2.81 \mathrm{~mm}$ 3 years after microscope-controlled glass bead blasting and a gain of $0.7 \mathrm{~mm}$ in clinical attachment level. Bleeding on probing and the plaque score were reduced from $29.5 \%$ to $0.85 \%$ and from $21.9 \%$ to $1.2 \%$, respectively, after 3 years. Most of the improvements in periodontal probing depth and clinical attachment level were seen in the first 6 months after treatment and were followed by stable periodontal conditions thereafter. This indicates that therapy with glass bead blasting is successful and leads to stable clinical results over a time span of 3 years.

All teeth showed improved clinical parameters; however, single-rooted teeth responded significantly better to treatment than did multirooted teeth. This is consistent with the existing periodontal literature ${ }^{27,28}$ in which single-rooted teeth showed better treatment results.

Working with the microscope has shown that untreated pockets of chronic periodontitis with a depth of more than $3 \mathrm{~mm}$ are always associated with hard deposits. ${ }^{23-26}$

Manual scalers and curettes should be used very carefully because they harm the root surfaces. Extracted teeth scalers shape the root rather than clean it. ${ }^{24}$ Ultrasonic scalers do less harm to the root surfaces, but perfect cleaning is not possible, as they glide over crevices. ${ }^{24-26}$

So the idea is to treat root surfaces with the glass blasting unit by Danville Engineering at varying pressures $(0.5-5$ bar $)$ under direct vision controlled by a microscope $\times 15-20$. Surface scanning electron microscopy in general showed that all root surfaces were smooth. Pressure of 0.5-5 bar and longer exposure produced even smoother root surfaces and did not injure or harm the teeth..$^{22}$

Inflammatory lesions caused by air insufflations were not seen. Caution should, however, still be exercised when performing this method. 
Table 3 Comparison of different root groups (root I: single-rooted teeth, root 2: premolars, root 3: molars)

\begin{tabular}{|c|c|c|c|c|c|c|c|}
\hline & Variable & Groups & Estimate & SE & df & $t$-value & $P$-value \\
\hline \multirow[t]{5}{*}{ Probing depth } & Intercept & & 3.4163 & 0.07552 & 23 & 45.24 & $<0.0001$ \\
\hline & Root & I vs 3 & -0.3787 & 0.05336 & 37 & -7.10 & $<0.000 \mathrm{I}$ \\
\hline & Root & 2 vs 3 & -0.2294 & 0.06955 & 37 & -3.30 & 0.0022 \\
\hline & Root & I vs 2 & -0.1493 & $0.0644 I$ & 37 & -2.32 & 0.0261 \\
\hline & Time & & -0.01606 & 0.000527 & 19E3 & -30.44 & $<0.0001$ \\
\hline \multirow[t]{5}{*}{ Attachment level } & Intercept & & 4.4736 & 0.2256 & 23 & 19.83 & $<0.0001$ \\
\hline & Root & I vs 3 & -0.1745 & 0.1536 & 37 & -1.14 & 0.2633 \\
\hline & Root & 2 vs 3 & -0.2910 & 0.1939 & 37 & -1.50 & 0.1420 \\
\hline & Root & I vs 2 & 0.1165 & 0.1783 & 37 & 0.65 & 0.5176 \\
\hline & Time & & -0.01297 & 0.000721 & I8E3 & -17.99 & $<0.0001$ \\
\hline \multirow[t]{5}{*}{ BOP } & Intercept & & $-|.673|$ & 0.3215 & 23 & -5.20 & $<0.0001$ \\
\hline & Root & I vs 3 & -0.1813 & 0.1586 & 38 & -1.14 & 0.2600 \\
\hline & Root & 2 vs 3 & 0.04574 & 0.2377 & 38 & 0.19 & 0.8484 \\
\hline & Root & I vs 2 & -0.227 I & 0.2238 & 38 & -1.01 & 0.3168 \\
\hline & Time & & -0.1891 & 0.01561 & I9E3 & -12.11 & $<\mathbf{0 . 0 0 0 1}$ \\
\hline \multirow[t]{5}{*}{ Plaque } & Intercept & & -1.9895 & $0.434 I$ & 23 & -4.58 & 0.0001 \\
\hline & Root & I vs 3 & -0.6831 & 0.1400 & 37 & -4.88 & $<0.0001$ \\
\hline & Root & 2 vs 3 & -1.0702 & 0.2256 & 37 & -4.74 & $<0.0001$ \\
\hline & Root & I vs 2 & 0.387 I & 0.2156 & 37 & 1.80 & 0.0808 \\
\hline & Time & & -0.1120 & 0.006357 & I9E3 & -17.62 & $<\mathbf{0 . 0 0 0 1}$ \\
\hline \multirow[t]{5}{*}{ OP } & Intercept & & -9.5664 & 1.3492 & 24 & -7.09 & $<0.0001$ \\
\hline & Root & I vs 3 & -1.3844 & 1.2230 & 39 & -1.13 & 0.2647 \\
\hline & Root & 2 vs 3 & -1.3199 & 1.7270 & 39 & -0.76 & 0.4494 \\
\hline & Root & I vs 2 & -0.0645 I & 1.6454 & 39 & -0.04 & 0.9689 \\
\hline & Time & & -0.2918 & 0.01532 & I9E3 & -19.05 & $<0.0001$ \\
\hline \multirow[t]{5}{*}{ GV } & Intercept & & -3.2549 & 0.377 I & 23 & -8.63 & $<0.0001$ \\
\hline & Root & I vs 3 & -1.9039 & 0.3614 & 37 & -5.27 & $<\mathbf{0 . 0 0 0 1}$ \\
\hline & Root & 2 vs 3 & -0.5104 & 0.4892 & 37 & -1.04 & 0.3035 \\
\hline & Root & I vs 2 & -1.3934 & 0.5194 & 37 & -2.68 & 0.0109 \\
\hline & Time & & -0.1562 & 0.02402 & I9E3 & -6.50 & $<0.0001$ \\
\hline \multirow[t]{5}{*}{ EMD } & Intercept & & -3.7853 & 0.5181 & 23 & -7.31 & $<0.0001$ \\
\hline & Root & I vs 3 & $-0.730 \mathrm{I}$ & 0.3340 & 37 & -2.19 & 0.0352 \\
\hline & Root & 2 vs 3 & $-0.5 \mathrm{I} 0 \mathrm{I}$ & 0.4378 & 37 & -1.17 & 0.2513 \\
\hline & Root & I vs 2 & -0.2200 & 0.4124 & 37 & -0.53 & 0.5970 \\
\hline & Time & & $-0.06 \mid 40$ & 0.003479 & I9E3 & -17.65 & $<0.0001$ \\
\hline \multirow[t]{5}{*}{$\mathrm{BIO}$} & Intercept & & -6.2930 & 0.7496 & 23 & -8.39 & $<0.0001$ \\
\hline & Root & I vs 3 & -1.0743 & 0.5728 & 37 & -1.88 & 0.0684 \\
\hline & Root & 2 vs 3 & -0.9089 & 0.8856 & 37 & -1.03 & 0.3112 \\
\hline & Root & I vs 2 & -0.1654 & 0.8546 & 37 & -0.19 & 0.8476 \\
\hline & Time & & -0.09904 & 0.01257 & 19E3 & -7.88 & $<0.0001$ \\
\hline
\end{tabular}

Abbreviations: BIO, Bio-Oss; BOP, bleeding on probing; EMD, Emdogain; GV, ((Author to define)); OP, ((Author to define)).

Table 4 Probing depth at baseline and 3, 6, 12, 18, 24, and 36 months

\begin{tabular}{|c|c|c|c|c|c|c|c|}
\hline & CPDO & CPD3 & CPD6 & CPDI 2 & CPD I 8 & CPD24 & CPD36 \\
\hline Min. & 1 & 1 & 1 & 1 & 2 & 1 & I \\
\hline Median & 3 & 3 & 3 & 3 & 3 & 3 & 3 \\
\hline Mean & 3.652 & 2.964 & 2.721 & 2.783 & $2.78 I$ & 2.821 & 2.813 \\
\hline Max. & 11 & 8 & 8 & 7 & 7 & 7 & 7 \\
\hline NAs & 423 & 3258 & 2028 & 2782 & 3257 & 2413 & 951 \\
\hline SD & 1.61 & 1.03 & 0.67 & 0.61 & 0.58 & 0.67 & 0.55 \\
\hline
\end{tabular}


Table 5 Attachment level at baseline and 3, 6, 12, 18, 24 and 36 months

\begin{tabular}{|c|c|c|c|c|c|c|c|}
\hline & ALO & AL3 & AL6 & ALI 2 & ALI 8 & AL24 & AL36 \\
\hline Min. & I & 2 & I & I & 1 & I & 2 \\
\hline Median & 4 & 4 & 4 & 4 & 4 & 4 & 4 \\
\hline Mean & 4.783 & 4.393 & 4.166 & 4.45 & 4.095 & 4.176 & 4.095 \\
\hline Max. & 14 & 12 & 12 & 10 & 10.5 & 10 & 9 \\
\hline NAs & 447 & 3398 & 2060 & 2792 & 3284 & 2429 & 989 \\
\hline SD & 2.24 & 1.98 & 1.51 & 1.53 & 1.27 & 1.52 & 1.33 \\
\hline
\end{tabular}

Table 6 Bleeding on probing, plaque score, EMD, and BIO at baseline and 3, 6, 12, 18, 24, and 36 months

\begin{tabular}{|c|c|c|c|c|c|c|}
\hline & BOPO & Plaque0 & OPO & GV0 & EMDO & BIOO \\
\hline 0 & 3252 & 3620 & 4616 & 4519 & 4208 & 4652 \\
\hline$\%$ & $67.33 \%$ & $74.95 \%$ & $95.57 \%$ & $93.56 \%$ & $87.12 \%$ & $96.31 \%$ \\
\hline I & 1424 & 1056 & 60 & 156 & 469 & 24 \\
\hline$\%$ & $29.48 \%$ & $21.86 \%$ & $1.24 \%$ & $3.23 \%$ & $9.71 \%$ & $0.50 \%$ \\
\hline NAs & 154 & 154 & 154 & 155 & 153 & 154 \\
\hline \multirow[t]{2}{*}{$\%$} & $3.19 \%$ & $3.19 \%$ & $3.19 \%$ & $3.21 \%$ & $3.17 \%$ & $3.19 \%$ \\
\hline & BOP3 & Plaque3 & OP3 & GV3 & EMD3 & $\mathrm{BIO} 3$ \\
\hline 0 & 1704 & 1708 & 1958 & 1960 & 1896 & 1930 \\
\hline$\%$ & $35.28 \%$ & $35.36 \%$ & $40.54 \%$ & $40.58 \%$ & $39.25 \%$ & $39.96 \%$ \\
\hline I & 18 & 14 & 38 & 36 & 100 & 66 \\
\hline$\%$ & $0.37 \%$ & $0.29 \%$ & $0.79 \%$ & $0.75 \%$ & $2.07 \%$ & $1.37 \%$ \\
\hline NAs & 3108 & 3108 & 2834 & 2834 & 2834 & 2834 \\
\hline \multirow[t]{2}{*}{$\%$} & $64.35 \%$ & $64.35 \%$ & $58.67 \%$ & $58.67 \%$ & $58.67 \%$ & $58.67 \%$ \\
\hline & BOP6 & Plaque6 & OP6 & GV6 & EMD6 & BIO6 \\
\hline 0 & 2912 & 2799 & 2928 & 2913 & 2930 & 2913 \\
\hline$\%$ & $60.29 \%$ & $57.95 \%$ & $60.62 \%$ & $60.31 \%$ & $60.66 \%$ & $60.31 \%$ \\
\hline I & 18 & $13 \mid$ & 10 & 25 & 8 & 25 \\
\hline$\%$ & $0.37 \%$ & $2.71 \%$ & $0.21 \%$ & $0.52 \%$ & $0.17 \%$ & $0.52 \%$ \\
\hline NAs & 1900 & 1900 & 1892 & 1892 & 1892 & 1892 \\
\hline \multirow[t]{2}{*}{$\%$} & $39.34 \%$ & $39.34 \%$ & $39.17 \%$ & $39.17 \%$ & $39.17 \%$ & $39.17 \%$ \\
\hline & BOPI 2 & Plaque I 2 & OPI2 & GVI2 & EMDI 2 & BIOI2 \\
\hline 0 & 2270 & 2185 & 2694 & 2682 & 2652 & 2692 \\
\hline$\%$ & $47.00 \%$ & $45.24 \%$ & $55.78 \%$ & $55.53 \%$ & $54.91 \%$ & $55.73 \%$ \\
\hline I & 75 & 160 & 0 & 12 & 46 & 2 \\
\hline$\%$ & $1.55 \%$ & $3.31 \%$ & $0.00 \%$ & $0.25 \%$ & $0.95 \%$ & $0.04 \%$ \\
\hline NAs & 2485 & 2485 & 2136 & 2136 & 2132 & 2136 \\
\hline \multirow[t]{2}{*}{$\%$} & $51.45 \%$ & $51.45 \%$ & $44.22 \%$ & $44.22 \%$ & $44.14 \%$ & $44.22 \%$ \\
\hline & BOP I 8 & Plaque I 8 & OPI 8 & GVI 8 & EMDI 8 & BIOI8 \\
\hline 0 & 2065 & 2058 & 2014 & 2010 & 1989 & 2014 \\
\hline$\%$ & $42.75 \%$ & $42.61 \%$ & $41.70 \%$ & $41.61 \%$ & $41.18 \%$ & $41.70 \%$ \\
\hline I & II & 18 & 0 & 4 & 25 & 0 \\
\hline$\%$ & $0.23 \%$ & $0.37 \%$ & $0.00 \%$ & $0.08 \%$ & $0.52 \%$ & $0.00 \%$ \\
\hline NAs & 2754 & 2754 & 2816 & 2816 & 2816 & 2816 \\
\hline \multirow[t]{2}{*}{$\%$} & $57.02 \%$ & $57.02 \%$ & $58.30 \%$ & $58.30 \%$ & $58.30 \%$ & $58.30 \%$ \\
\hline & BOP24 & Plaque24 & OP24 & GV24 & EMD24 & BIO24 \\
\hline 0 & 2637 & 2622 & 2742 & 2742 & 2591 & 2734 \\
\hline$\%$ & $54.60 \%$ & $54.29 \%$ & $56.77 \%$ & $56.77 \%$ & $53.64 \%$ & $56.60 \%$ \\
\hline I & 69 & 84 & 0 & 0 & 151 & 8 \\
\hline$\%$ & $1.43 \%$ & I.74\% & $0.00 \%$ & $0.00 \%$ & $3.13 \%$ & $0.17 \%$ \\
\hline NAs & 2124 & 2124 & 2088 & 2088 & 2088 & 2088 \\
\hline \multirow[t]{2}{*}{$\%$} & $43.98 \%$ & $43.98 \%$ & $43.23 \%$ & $43.23 \%$ & $43.23 \%$ & $43.23 \%$ \\
\hline & BOP36 & Plaque36 & OP36 & GV36 & EMD36 & BIO36 \\
\hline 0 & 4346 & 4327 & 4546 & 4542 & 4465 & 4546 \\
\hline$\%$ & $89.98 \%$ & $89.59 \%$ & $94.12 \%$ & $94.04 \%$ & $92.44 \%$ & $94.12 \%$ \\
\hline
\end{tabular}


Table 6 (Continued)

\begin{tabular}{|c|c|c|c|c|c|c|}
\hline & BOP36 & Plaque 36 & OP36 & GV36 & EMD36 & B1036 \\
\hline I & 41 & 60 & 0 & 4 & 81 & 0 \\
\hline$\%$ & $0.85 \%$ & $1.24 \%$ & $0.00 \%$ & $0.08 \%$ & $1.68 \%$ & $0.00 \%$ \\
\hline NAs & 443 & 443 & 284 & 284 & 284 & 284 \\
\hline$\%$ & $9.17 \%$ & $9.17 \%$ & $5.88 \%$ & $5.88 \%$ & $5.88 \%$ & $5.88 \%$ \\
\hline
\end{tabular}

Abbreviations: BIO, Bio-Oss; BOP, bleeding on probing; EMD, Emdogain; GV, ((Author to define)); OP, ((Author to define)).

Microscope-controlled glass bead blasting removes biofilm, deposits, and granulation tissue and creates optimal conditions for tissue regeneration. The treatment of incisors, canines, and premolars carries a very good prognosis, because these teeth are single or double rooted and easily accessible.

The prognosis for molars is equally good for the external and internal facets of molar roots. Furcation has mostly defied treatment in the past, as cleaning the teeth was not visually controllable and was largely left to chance. But direct visual control has its limitations. When furcations fold inward into the dome, the height of the gingival cuff usually impairs or altogether prevents direct vision, even when using glass beads. This factor limits the applicability of the procedure. In this case, one incision tunnel flap surgery was done.

With microscope-controlled glass bead blasting, the distal molar facets, which have so far escaped visual control during conservative therapy, have become amenable to perfect cleaning supra- and subgingival. Visual control is, however, bound to be indirect and places major demands on the skills of the dental assistants. Buccal, palatal, and mesial facets, by contrast, can usually be seen easily.

The air jet of the unit bombards the tooth surfaces with glass beads and blows these into the sulcus. Whether or not some glass beads may stay in the sulcus is not clear. This is still an unresolved question.

The author has successfully used this procedure, which has revolutionized paradigms of periodontal treatment.

\section{Acknowledgment}

This work is dedicated to the International College of Dentists.

\section{Disclosure}

The authors report no conflicts of interest in this work.

\section{References}

1. Flemming TF. Parodontologie, New York: Georg Thieme, Stuttgart; 1993.

2. Black RB. Technic for nonmechanical preparation of cavities and prophylaxis. J Am Dent Assoc. 1945;32:955-965.
3. Kotschy P. Die Systematik der funktionsorientierten zahnärztlichen Diagnostik und ihre karteimäßige Erfassung. Öster Stomatol. 1976;12:445-449.

4. Kotschy P. Die Dokumentation der Anamnese, Befunderhebung, Diagnostik und Therapie in der Zahn-, Mund- und Kieferheilkunde. Öster Stomatol. 1979;6:214-220.

5. O-Leary TJ, Drake RB, Naylor JE. The plaque control report J Periodontol. 1972;43:38-39.

6. Badersten A, Nilvéus R, Egelberg J. Effect of nonsurgical periodontal therapy. I. Moderately advanced periodontitis. J Clin Periodontol. 1981;57:72.

7. Badersten A, Nilvéus R, Egelberg J. Effect of nonsurgical periodontal therapy. II. Severely advanced periodontitis. J Clin Periodontol. 1984;11:114-124.

8. Laurell L, Pettersson B. Periodontal healing after treatment with either the Titan-S sonic scaler or hand instruments. Swed Dent J. 1988;12: 187-192.

9. Heitz-Mayfield LJA. How effective is surgical therapy compared with nonsurgical debridement? Periodontol. 2000;37:72-87.

10. Hammarström L, Heijl L, Gestrelius. Periodontal regeneration in a buccal dehiscence model in monkeys after application of enamel matrix proteins. J Clin Periodontol. 1997;24:669-677.

11. Gestrelius S, Andersson C, Lidström D, et al. In vitro studies on periodontal ligament cells and enamel matrix derivates. $J$ Clinical Periodontol. 1997;24:685-692.

12. Heijl L, Heden G, Svärdström G, Östgren A. Enamel matrix derivative in the treatment of intrabony periodontal defects. J Clin Periodontol. 1997;24:705-714.

13. Heijl L. Periodontal regeneration with enamel matrix derivative in one human experimental defect: a case report. J Clin Periodontol. 1997;24: 693-696.

14. Mellonig JT. Enamel matrix derivative for periodontal reconstructive surgery: technique and clinical and histologic case report. Int $J$ Periodontics Restorative Dent. 1999;19:9-19.

15. Secheyer ET, Velasquez-Plata D, Brunsvold MA, et al. A clinical comparison of a bovine derived xenograft used alone and in combination with enamel matrix derivative for the treatment of periodontal osseous defects in humans. J Periodontol. 2002;73:423-432.

16. Velasquez-Plata D, Scheyer ET, Mellonig JT. Clinical comparison of an enamel matrix derivative use alone or in combination with a bovine-derived xenograft for the treatment of periodontal osseous defects in humans. $J$ Periodontol. 2002;73:433-440.

17. Zetterström O, Anderson C, Eriksson A, et al. Clinical safety of enamel matrix derivative (Emdogain) in the treatment of periodontal defects. J Clin Periodontol. 1997;24:697-704.

18. Camargo PM, Lekovic V, Weinlaender M, et al. The effectiveness of enamel matrix proteins used in combination with bovine porous bone mineral in the treatment of intrabony defects in humans. $J$ Clin Periodontol. 2001;28:1016-1022.

19. Lekovic V, Camargo PM, Weinlaender M, et al. A comparison between enamel matrix proteins used alone or in combination with bovine porous bone mineral in the treatment of infrabony periodontal defects in humans. $J$ Periodontol. 2000;71:1110-1116.

20. Nanci A, Bosshardt DD. Structure of periodontal tissues in health and disease. Periodontol. 2000;40:11-28. 
21. Cortellini P, Pini Prato G, Tonetti MS. The modified papilla preservation technique. A new surgical approach for interproximal regenerative procedures. J Periodontol. 1995;66:261-266.

22. Virnik AS, et al. Electron microscopic investigation of a glass bead blasting unit. (Still in progress).

23. Kontturi-Närhi V, Markhanen S, Markhanen H. Effects of airpolishing on dental plaque removal and hard tissues as evaluated by scanning electron microscopy. J Periodontol. 1990;61:334-338.

24. Ewen J. A scanning electron microscopic study of teeth following periodontal instrumentation. J Periodontol. 1977;48:92-97.

25. Garnick JJ, Dent J. A scanning electron micrographical study of root surfaces and subgingival bacteria after hand and ultrasonic instrumentation. J Periodontol. 1989;60(8):441-447.
26. Leon LE, Vogel RI. A comparison of the effectiveness of hand scaling and ultrasonic debridement in furcations as evaluated by differential dark-field microscopy. J Periodontol. 1987;58:86-94.

27. Wasserman B, Hirschfeld L. The relationship of initial clinical parameters to the long-term response in 112 cases of periodontal disease. J Clin Periodontol. 1988;15:38-42.

28. Hirschfeld L, Wasserman B. A long-term survey of tooth loss in 600 treated periodontal patients. J Periodontol. 1978;49: 225-237.

29. Kotschy P. Optimal root cleaning and microinvasive periodontal pocket surgery with microscope-controlled glass bead blasting. Int J Microdent. 2010;2:48-55.

\section{Publish your work in this journal}

Clinical, Cosmetic and Investigational Dentistry is an international, peer-reviewed, open access, online journal focusing on the latest clinical and experimental research in dentistry with specific emphasis on cosmetic interventions. Innovative developments in dental materials, techniques and devices that improve outcomes and patient satisfac- tion and preference will be highlighted. The manuscript management system is completely online and includes a very quick and fair peerreview system, which is all easy to use. Visit http://www.dovepress. com/testimonials.php to read real quotes from published authors.

Submit your manuscript here: http://www.dovepress.com/clinical-cosmetic-and-investigational-dentistry-journal 